\title{
The role of social capital in enhancing community disaster preparedness and building back better in recovery
}

\author{
Deny Hidayati ${ }^{1, *}$ \\ ${ }^{1}$ Research Centre for Population, the Indonesian Institute of Sciences (P2K-LIPI), Gatot Subroto Street No.10, Jakarta, 12190, \\ Indonesia
}

\begin{abstract}
As a country with high risk of disasters, the people of Indonesia have to prepare and anticipate these calamities. One of the most important aspects of disaster risk reduction at the local level is social capital. This paper discusses the role of social capital in strengthening community disaster preparedness for effective respond and its potential for building back after recovery, focusing on local wisdom, prior experiences and re-establishment of community livelihoods. Local wisdom plays an important role in raising community efforts to find relief and recover from the impact of the earthquake in Bantul and floods in Jambi. The spirit of community-self, mutual help and fundraising help the Javanese in Bantul to be strong and care among neighbors. The community that supported by the local leaders and institutions agreed to set up priority for affected people who need more help. Meanwhile, experiences of the people in Jambi on regular floods made them aware and assisted them to develop self-efficacy beliefs in disaster preparedness, including making plans as well as increasing skill to get ready for and respond to this disaster. This paper also shows that in addition to economic recovery programs from the government and donor in Bantul and Aceh, the community in Jambi used floods as a source of their alternative livelihood through fishing and its related activities, and perceived floods as economic opportunities. This paper utilises empirical evidence from cases across Indonesia that are collected from my research results under LIPI and Human Ecology research activities. Data is also collected from secondary sources that largely rely on desk reviews of relevant books, documents, papers, and other references.
\end{abstract}

\section{Introduction}

Disasters in Indonesia continue to increase in frequency and magnitude. National Disaster Management Authority (BNPB) informs that the increase was about 10 percent during the last 10 years, causing about 155 people died per year, 10,518 people injured, and 300,630 people had to be evacuated during this period [1]. Indonesia, geographically and geologically, lies in a region that is vulnerable to natural disasters and thus it is prone to natural and man-made calamities. Many types of disasters, including earthquakes, tsunamis, floods, and landslides, have frequently occurred in recent times in most parts of the country. The underlying drivers, including rapid resource exploitation, forest degradation, climate change, and urbanization, are closely related to the increasing number of people, livelihoods, and assets exposed to natural and manmade hazards.

Indonesia, according to the word risk report, is ranked 34 out of 171 countries in terms of risks to various hazards. This report points out that Indonesia had a "very high" risk and exposure, "high" vulnerability and susceptibility, and lack of coping and adaptive capacities [2]. Most Indonesian provinces and their coastal areas, in particular, were identified as "disaster high risk," yet more than half of the total population live in and are dependent on these areas [1].
Realizing the high risk of disasters, the people of Indonesia have to prepare to anticipate these events. The importance of preparedness has been stated in the Disaster Management Law Number 24 in 2007 and the Government Regulation Number 21 in 2008. Various initiatives on community disaster preparedness have been executed throughout the country since the Aceh tsunami in 2004. Increasing knowledge and raising awareness of hazards and the skills to manage disasters become the main focus of disaster risk reduction.

A variety of education and preparedness activities and channels has been developed and implemented by disaster education groups and relevant stakeholders. Initiatives include formal and non-formal education programs and public campaigns. They developed educational books and materials with different types of information of different quality levels. Some contain information about natural processes and disasters integrated with life skills and enjoyable learning activities applicable to the tsunami and other disaster areas. However, there are other books and materials that contain information without considering scientific standards on natural processes and disasters.

The community has increased their knowledge. However, it is mostly not being followed by preparedness actions in spite of the fact that they live in high-risk areas and their exposure level is very great. The people preparedness, therefore, remained weak [3,

Corresponding author: gatsu.1t10@yahoo.com 
4]. The households were still lacking in preparation for providing 1) emergency planning (such as evacuation places and routes, evacuating skills and drills, as well as first aids and emergency kit); 2) access of information about early warning and for responding to the warning; 3) enough capacity of household resource mobilization, including information and skills to save lives and reduce the disaster risks.

This feature is based on LIPI studies on community preparedness in anticipating earthquake and tsunami in the City of Bengkulu and Ternate, as well as the Districts of Biak, Cilacap, Padang Pariaman, and Serang. This condition also applies to other locations with different disasters, including floods and landslides in the districts of Kebumen and Pesisir Selatan [5], and floods and fires in the West Jakarta $[6,7]$.

The increase of disaster's risk and exposure of lives and assets indicates the crucial need to strengthen existing preparedness for effective response and action in anticipation of events. Lessons learned from previous disasters inform that rebuilding communities with predisaster standards will recreate previously existing vulnerabilities and expose them to continuing devastation from future calamities [8,9]. Locals need to be socio-economically supported to recover from trauma experienced and move forward with their lives and livelihood.

Previous disasters indicated that enhancing preparedness and social recovery often overshadows the disaster risk reduction. Even cuts across different aspects, it focuses more on improving the structural designs of the built environment and hazard-based land-use to avoid or manage prevalent risks. Another important lesson is that recovery, rehabilitation and reconstruction phases need to be prepared before the disaster occurs. The short-term emergency response, therefore, has to be linked with long-term resilience building efforts.

\section{Objectives and method}

This paper aims to discuss the roles of social capital in enhancing community preparedness for effective response and building back better after the disaster event. These two elements are the key of the Sendai Framework, especially priority 4.

This paper is based on empirical evidence from cases across Indonesia. The evidence is gathered from LIPI, Human Ecology and my own research results that are relevant to this topic. These include assessing level of community vulnerability and preparedness in anticipating earthquake and tsunami in Indonesia, consisting of the District of Padang Pariaman and Bengkulu (Sumatra) in 2006; the districts of Serang, and Cilacap (Java), as well as the City of Ternate (Maluku) and the District of Biak (Papua) in 2008; Gender Roles in Post Disaster Management in Bantul (Yogyakarta) in 2011; community preparedness in anticipating floods and landslides in Kebumen and Pesisir Selatan in 2010; the role of local wisdom in the Javanese survival strategy in facing the 2006 Bantul Earthquake in 2011; community preparedness in anticipating floods and fires in the City of West Jakarta in 2015; and community resilience in facing environmental changes as well as their related disasters in Jambi and Medan from 2014 to 2017.

All the researches applied the qualitative method, while researches on community disaster preparedness also utilized a quantitative survey. The qualitative method used focus group discussions (FGDs) with fishermen and/or farmers, women and youth groups; open interviews with key informants, such as with formal and non-formal leaders, representatives of fishermen and/or farmers, women, youth groups and local community organizations; workshops with government institution officials; and field observations. The quantitative method is based on a questionnaire (closed questions) survey of 200 household respondents that were randomly chosen.

This paper also uses the secondary data collection that largely relies on desk reviews of relevant books, documents, papers, and other references. The review is carried out to gain more understanding of relevant concepts and theories, such as social capital, local wisdom, preparedness, social learning and build back better; and their link to this topic.

\section{Result and discussion}

Strengthening preparedness for a response before the disaster and mobilizing necessary capacities and resources during and after its event plays a major role in disaster risk reduction. This indicates that recovery, rehabilitation, and reconstruction plans should be prepared ahead of and integrated into pre-disaster to enable build back better as noted in priority 4 of the Sendai Framework [10].

\subsection{The linkage between social capital with disaster preparedness and build back better}

Social capital is one of the most important aspects of disaster risk reduction at the local level. This potential is rooted in the concept of social capital. Definition of social capital varies according to references, such as 'the ability of people to work together for common purposes in groups and organizations' [11] and 'the existence of a certain set of informal values or norms shared among members of a group that permits cooperation among them' [12]. Social capital is also described as 'networks, together with shared norms, values, and understandings which facilitate cooperation within or among groups' [13]. It refers to the social structure, obligation and expectation, information channels and set of norms and effective sanction that enforce and/or drive certain kinds of behavior [14]. In summary, social capital is invented as social obligations and connections within members of a community group [15] which is embedded in every community member.

Previous disasters show the important role of social capital. This paper discusses forms of social capital that are closely linked to community preparedness during 
disasters, how to survive and rise from adversity in the recovery period.

Enhancing disaster preparedness for effective response remains a critical component. The care and capacity of communities throughout Indonesia need to be paid serious attention in order to reduce their disaster risks. The increase in their preparedness sources from social learning in the form of new knowledge and skill or prior experiences.

What is being learned from disaster risk reduction is the capacity to live with uncertainty and risk. The capacity can be developed through social learning by retaining additional knowledge and skill that can be collected through a cyclical process from external ideas and intrinsic consideration.

Social learning is 'a process of collective and communicative learning, which may be resulted in a number of social outcomes, new skills and knowledge' [16]. It is an on-going, adaptive process of developing new knowledge from individuals or groups through social interaction that results in changes to social structures [17]. Social learning is also defined as learning that 'goes beyond the individual', to be embedded within social networks [18].

Through social learning, individuals or actors interact with each other and have access to technology and other resources. Learning through share-learning amongst peers is assumed to be faster and deeper compared to that obtained through the socialization from an instructor only $[19,20]$. They develop their capacities for engaging with others, including from government or relevant institutions, such as education and environmental agencies, practitioners, and NGOs. This engagement is enabling them to take relevant actions to enable build back better.

The term 'build back better' (BBB) became popular during the reconstruction phase after the 2004 giant tsunami in Aceh. The motivation was to help to get the communities stronger after the devastating disaster. Back then, post-disaster recovery was crucially needed to restore communities and assets in a manner, reducing vulnerability to future disaster and strengthening their resilience.

The BBB concept addresses the importance of strengthening community resilience after the disaster event. It has been defined as a method to make use of the reconstruction process to improve a community's physical, social, economic and environmental conditions to gain a more resilient community [21, 22]. This concept shows that the core idea of BBB is community recovery [8].

\subsection{The roles of local wisdom}

Local wisdom, a social capital of the community, is a collection of traditional knowledge, norm, rules, and skills that have been passed through generations to meet their need [23, 24].

Local wisdom plays an important role in raising community efforts to find relief and recover from the impact of the disaster. Knowledge, values, and action can develop in harmony to enhance individual or group's capacity to build disaster resilience.

Smong is a local wisdom in Simeulue Island, Aceh, that saving most of its people when giant tsunami occurred in 2004. It is a natural warning system for the people on this island if a strong earthquake struck, then the water receded, the people have to run away to a higher and safer place. This wisdom is based on their experience when facing a great earthquake and tsunami in 1907. This disaster caused the death of most people on this island. The survivors shared their experience through storytelling (such as lullaby, traditional poems, and songs) that inherited from generation to generation.

When facing a devastating earthquake in 2006, the Javanese in the District of Bantul utilized the local wisdom for their survival and reducing the risk of further disaster impacts. Local wisdom is closely related to prevailing customs and culture in the location, comprising community self-help, mutualhelp/cooperation and fundraising. They also shared the role by gender and set up aid priority to more needy and affected people $[25,26]$.

The spirit of mutual-help made the Javanese in this district strong and caring among neighbors. The fervor within a community and values of harmony and togetherness were the key elements in facilitating the effectiveness of the recovery efforts during the emergency and reconstruction phases.

The community with technical assistance from professionals worked together to reconstruct the damaged houses. The earthquake caused severe infrastructure damage in this district with the total of the destroyed house was about 236,024 [27]. Their participation in the mutual-help proved to be effective in the reconstruction process. The mutual cooperation actually had been started since the critical time - the first three days after the earthquake. They quickly built temporary shelters using materials available in surrounding areas, such as material from the ruined houses, and inventory of the community, such as tents, roofing zinc and mats [26].

At the beginning of the reconstruction, the community, the hamlet leader and informal leaders agreed to set up prioritized households to receive government support for housing reconstruction. The priority was households with a member in early childhood or of old age and from poor families as well as those that suffered the most in the disaster. The agreed priority was a reflection of the sense of solidarity and respect for the people who needed more help [28].

What has been done by the community in Bantul demonstrates valuable lessons in disaster risk reduction. The ability of the community to manage local wisdom needs to be maintained and nurtured. Participation of the community in addressing emergency and recovery conditions is very meaningful and becomes a key aspect in building back better.

\subsubsection{The importance of local leaders and institutions}


The roles of local institutions (formal and informal) are also essential, particularly in supporting the community survival and reducing further risk of disaster. The community organizations, both in Hamlet and/or in village levels, can also play an important role, particularly in activating the community, especially during and post-disaster. Increasing the capacity of local leaders and institutions (such as Hamlet and neighborhood organizations, religious groups, women groups, fishermen/farmers' groups) is needed, especially in relation to efforts in enhancing community preparedness and resiliency.

The roles of local leaders and institutions vary among disaster locations, some significant and others still lacking. The role of local leaders and institutions in handling earthquake in Bantul has become a good lesson learned for disaster risk reduction in Indonesia. Local institutions, both formal (neighborhood, the hamlet, and village) and informal (kinship and paguyuban) played a major role, especially during the first three days after the earthquake and in the emergency phase.

The significant contributions of local institutions in the case of Bantul earthquake are to mobilize the community to meet their needs, using the local wisdom that still exists throughout the district and their awareness of disaster victims who needed more help. This role was also supported by the leadership of the Head of Bantul District and the Sultanate of Yogyakarta. In addition, stakeholders and donors-national and international-also provided a significant support, particularly in the provision of food stock, health services and reconstruction of damaged houses.

The important role of local leaders is also found in Kampung Aur in the City of Medan. The head of hamlet and youth groups play a significant role in facing flood, especially in reducing the disaster impacts in this area. They have a high awareness of security and safety of the people in this kampong because the floods often occur in this area. When the warning is received, either from the natural signs of the river water flowing through the kampong or from the government, the head of the head of hamlet distributes and announces the flood warning to the people through mosques. He also asks them to prepare, especially for those who are in vulnerable areas, especially along the river and low-lying settlements.

When water comes up to their settlement and inundated the houses, the youth groups will move quickly to help the victims - especially the children, the elderly and residents who need help. They evacuate them to safe places that have been designated earlier, mostly in their relative's houses. They also ensure that none of the houses would be washed away during the flood. The local leaders and youth groups have a close relationship with the local and city government. They, therefore, would quickly obtain relief, especially from the disaster management office (BPBD) in Medan [29].

Another face of local leaders and institutions is that although they have important roles in disaster management, some are still weak in delivering their contributions. This phenomenon is still widespread throughout the country and unfortunately affects disaster-prone areas. In this case, the role of local leaders and institutions in distributing warning for disasters (landslides) is still low, particularly in vulnerable areas. In the district of Pesisir Selatan, for example, the warning is only provided through a small billboard on the roadside prone to landslides.

\subsubsection{The importance of share roles by gender}

Understanding gender dynamics and involving women within the framework of disaster risk reduction are critical factors for developing effective preparedness, rehabilitation. Male participation is needed to conduct vulnerability mapping and increase people's capacity to reduce risks. This indicates one of the most important gender roles, not only on the family scale but also on a much larger scale in disaster policies and programs. Gender roles and relations in social dimensions influence the capacity of women and men to respond to disaster although place women at greater risk than men.

The Bantul earthquake provides a lesson in the role of gender when the community facing disaster, especially during the event and emergency phase. They automatically shared roles, men's group (men and youth) and women's group (women and teenage daughters) based on their domain. The domain of male activities was that of activities requiring 'energy', 'muscle' and 'courage'. The rescue and evacuation effort of the victims was carried out immediately after the earthquake had subsided.

The domain of women activities was related to domestic activities, such as daily livelihood and activities that require thoroughness and diligence [30]. Women were in charge of preparing cooked food and distributing it to the earthquake survivors. Women also focused on rescue and search for children and members of their families. Women had the top priority that is family salvation. In addition, women and men in some activities worked together. Women and men, especially community leaders and youth, actively participated in collecting and distributing food aid.

A different picture occurred in the Aceh tsunami. Gender inequality appeared where both men and women acted heroically to survive and at the same time suffered severe trauma and dislocation. However, gender relations limited women's ability to respond to this devastating disaster. Cultural norms halted women from gaining relief services. For example, food distribution was targeted to the male heads of the household while the women heads of households became marginalized. Women's skills, roles and specific experiences in disaster risk reduction should be considered as inputs and important factors in developing preparedness, mitigation, and rehabilitation phases

Access and participation of men and women, however, was still limited. Therefore, it needs to be increased, particularly in relation to efforts in reducing disaster risks, such as increasing their skill for first aid and rescuing victims, through regular training and simulation. 


\subsection{The role of prior experiences}

People's experiences with extreme, severe or regular natural events can motivate people to take action to lower the risks $[31,32]$. Their experiences assist their beliefs about whether and how they have to face disasters, such as earthquake or flood.

Several preparedness theories and approaches demonstrate that prior experience of disasters has an effect on the preparedness process [33]. Direct and indirect experience can be a motivator of preparedness for future disaster. Direct experience of disaster would become a strong motivator because the event strongly influences the memory. The effect includes encouraging thinking and talking; increasing awareness and knowledge; assisting individuals to understand the consequences of a disaster; evolving beliefs; raising preparedness; influencing emotions and feelings; and encouraging community interaction on disaster issues [34].

Experience, belief, and preparedness have a close link that might become a contingent on reducing disaster risk. The experiences of Jambi people in facing regular floods are very useful for them to be aware of what and how to prepare and respond. Their experiences assist in developing self-efficacy beliefs in disaster preparedness, including making plans as well as increasing skill to get ready for and respond to a disaster.

Research conducted by human ecology team of P2K LIPI in 2017 showed a high preparedness of the people in Seponjen and Mekarsari Villages in the District of Muaro Jambi in facing floods that frequently occur in these villages. Before floods come, they build ambenamben that function as safe places within their houses. They use amben for many purposes, such as places to put valuable goods, to cook and eat, to rest and sleep when flood inundates their houses. They also prepare small boats with and/or without a machine as means of water transportation during the flood. The boat is very important for them so that they are not isolated during the flood which usually takes up quite a long time, about three to six months per year. Boats are vital transportation for their daily activities, including going to school for children, to farmlands and gardens for farmers, shopping for family needs and other social activities. The villagers who have motorcycles also move and park them in safe places. In addition, some individuals and households also increase their skill by learning how to swim and rowing boat and prepare daily basic need for their own households [35].

Meanwhile, the people in Seponjen Village have an important effort to mitigate floods. They build the mooring houses, mostly made of wood. This habit has been going on since their parents. The mooring house is aimed to maintain their security and safety, not only from the flood but also from disturbance of wild animals.

In contrast, even flood often occurs in Duri Utara and Pinangsia Sub-districts in West Jakarta; the people seemingly have not learned much from the disaster. The community's preparedness, both men, and women are still limited. They do not take into account the disaster as lessons learned. Flood is still perceived as a natural event that routinely happens during the rainy season-in Pinangsia, it also happens during tidal flooding.

Their awareness of flood warning is lacking and thus not optimal in preparing and fulfilling concrete steps to minimize the disaster risk. The situation is worse because their socio-economic condition is also limited. These conditions affect their capacity to increase preparedness in anticipating flood [7].

\subsection{The role of livelihood re-establishment}

Lessons from previous disasters in Indonesia indicate that a community living under limited socio-economic conditions has difficulty in recovering its economic wellbeing. They face difficulties in providing for their basic needs, especially before relief from governments and other donors arrives. Poverty affects their lack of capacity to prepare for basic daily needs, including food, health services, and housing.

\subsubsection{Economic recovery programs}

The impacts of disasters on the economy can also hinder the overall recovery. The Aceh tsunami demonstrated a disaster's long-term effects on the province's economy. The important part of recovery was to support the economic recovery of the community and regeneration of their livelihood. Some programs had been initiated, such as conducting skill-training programs for the affected people, providing job opportunities and employing them in reconstruction works. Another important scheme was to provide financial help and grants for micro-enterprise and small-scale business.

The first three days after a disaster is a critical time for victims when they are in an emotional and traumatic state and the provision of food and shelter is usually still lacking since food and shelter relief from outside has not yet fully reached the disaster locations.

During the emergency and earlier time of recovery phase, the survival of the affected people livelihood in Bantul was dominated and supported by social networks, both local and external. Intra-family relations played an important role in helping their own family members, while the external groups mostly supported the vulnerable group.

During the rehabilitation and reconstruction phase, the livelihood recovery was mostly provided by donor agents through the recovery programs. This condition was implemented in all disaster areas. In addition to this relief, Bantul also applied a local government program called Bantul Bangkit as an effort to move and speed up the recovery. The focus was to endorse the recovery of micro, small and medium enterprises. These efforts provided job opportunities and improved the people's livelihoods [36].

The provision of jobs was very crucial and needed in Bantul. The earthquake had a devastating effect on the livelihood of its people. About 32 thousands of workers 
had lost their jobs, especially in manufacturing, services, and trade. This condition had a significant impact on the economic life of the community, indicated by the increasing number of poor families, which was about 3.3 percent [37].

\subsubsection{Creating economic opportunities from disasters}

Despite the implementation of the types of initiatives mentioned above, another form of disaster economic recovery is to utilize disaster condition as a source for money-making activities. Research result from Jambi shows that many Jambi people use flood for fishery activities. In Seponjen and Mekar Sari Villages in the District of Muaro Jambi, floods occur 2-3 times per year for a period of 3-6 months. Most of the villagers in these areas are farmers, usually in the plantation (especially palm oil and rubber) and food crops (mainly rice, maize, and vegetables). During the flood, their economic activities are significantly disrupted because their plantation and farmlands are inundated. Their palm oil and rubber productivity decrease significantly. Most farmers are unable to grow food crops. Consequently, they have to delay the planting time of the crops until the end of flooding.

The farmers in these two villages utilize floods as economic opportunities to catch fish. Many farmers temporarily change their job to be fishermen. Fishing becomes an important alternative economic activity and source of cash income during this event. Fish production from the floods is relatively high. This is indicated by most of the fish are sold to fish middlemen who sell them back to markets, not only in surrounding towns and Jambi City but is also exported to other provinces like South Sumatra, especially in Palembang City.

In addition to selling fresh fish, many of them also processed it into salted fish. This activity has value added, not only because the fish last longer but the unit price is also more expensive. They usually wait to sell the salted fish until the dry season when fish production in these areas is limited.

By utilizing floods as a source of livelihood, some people in Jambi, especially in these two villages, perceive that flooding is not a disaster, but a blessing from God. Some people mentioned that the longer flood, the better so they can catch more and bigger fish. Their belief is that living in harmony with nature, including floods, is a 'grace' that must be accepted and maintained well for the sustainability of their livelihood.

\section{Conclusions}

This paper shows that social capital plays an important role in enhancing community disaster preparedness for effective response, as well as high potential for building back better after recovery at the local level. The social capital of the Javanese in Bantul draws strong networks among individuals and communities and provides social support, access to various resources in times of their need. These elements improve their ability through their norms, kinship, and togetherness to meet their common necessity.

Social capital incorporated with disaster preparedness is essential to create new networks and activities that focus specifically on the reduction of disaster impacts and sustainable livelihood. The Javanese local wisdom can be applied as a social investment in generating and developing their preparedness and resilience. The spirit of mutual cooperation, that is a joint bearing of burdens among the community members with volunteerism characteristics, and the community values of providing priority for affected people who need more help are very crucial and helpful. This social capital needs to be maintained and used as lessons learned by people in other disaster-prone areas of Indonesia.

The prior experiences of the community in Jambi significantly influence their preparedness to reduce disaster impacts and future flood risk. Experiences derive from people's own accounts inform their preparedness thinking and decision making. The importance of experience, direct and/or indirect, needs to be paid more attention.

Another important lesson from this paper comes from the community in Jambi that use floods as a source of their livelihood. The community perceived floods that regularly occur as an economic opportunity. The fish in the flooding areas sold most of the fresh fish and processed the rest to become salted fish. This activity is very valuable and crucial for sustaining their livelihood.

This paper shows that strengthening community preparedness is still a critical component in disaster risk reduction and building back better in Indonesia. A more comprehensive action plan, therefore, should be carried out to meet the urgent requirement of the community, enliven local wisdom and utilize local resources. Efforts to improve community preparedness need to be applied through activities that are locally friendly and based on a community participatory approach. These efforts should be integrated into policies and programs for sustainable development and poverty reduction through regional and international cooperation and partnerships as called by priority 4 of the Sendai Framework.

I would like to thank LIPI and Human Ecology teams for permits to use their relevant research results, and for their support to this paper.

\section{References}

1. BNPB. Indonesian Disaster Data and Information. Jakarta, Indonesia: BNPB, (2014) (In Indonesia)

2. M.W. Beck, Ed., Coasts at Risk: An Assessment of Coastal Risks and the Role of Environmental Solutions. A joint publication of United Nations University - Institute for Environment and Human Security (UNU-EHS), The Nature Conservancy (TNC) and the Coastal Resources Center (CRC) at the University of Rhode Island Graduate School of Oceanography. (2014)

3. D. Hidayati, "Striving to reduce disaster risk: vulnerable communities with low levels of 
preparedness in Indonesia," Journal of Disaster Research., vol.7 No.1, pp. 75-82, Jan. 2012

4. D. Hidayati, Community Preparedness: A New Paradigm in Disaster Management in Indonesia, D. Mardianto and M. Takahashi, Ed. Yogyakarta, Indonesia: Gajah Mada University Press, (2012)

5. D. Hidayati, Widayatun, and Ngadi. Community Preparedness in Anticipating Floods and Landslides in the Districts of Kebumen and Pesisir Selatan. Jakarta, Indonesia: PT Gading Inti Prima, (2012)

6. D. Hidayati, Ed., Community Preparedness in Anticipating Fires and Floods in Jakarta Barat. Tangerang, Indonesia: Mahara Publishing, (2016)

7. I.A.P. Putri, Widayatun, and D. Hidayati. Community Preparedness in Anticipating Floods. Tangerang, Indonesia: Mahara Publishing, (2016)

8. S. Mannakkara, "A framework for building back better during post-disaster reconstruction and recovery," Doctor of Philosophy Civil Engineering. thesis, The University of Auckland. (2014)

9. O. Patterson, F. Weil, and K. Patel. "The Role of Community in Disaster Response: Conceptual Models 2010," Popul Res Policy Rev 29, pp. 127141, (2010)

10. United Nations, Sendai Framework for Disaster Risk Reduction 2015-2030, United Nations, 2015, p. 35, 〈http://www.unisdr.org/ files/43291_sendaiframeworkfordrren.pdf $\rangle$.

11. F. Fukuyama, Trust: The Social Virtues and the Creation of Prosperity. New York: The Free Press, (1995)

12. F. Fukuyama. "Social capital, civil society, and development," Third World Quarterly, 22(1), pp. 720, (2001)

13. OECD. The Wellbeing of Nations: The Role of Human and Social Capital, Education and Skills. Paris, France: OECD Centre for Educational Research and Innovation, (2001)

14. J.S. Coleman. "Social capital in the creation of human capital," American Journal of Sociology, (94), pp. 95-120, (1988)

15. N. Lin. Social Capital a theory of Social structure and Action. Cambridge: Cambridge University Press, (2001)

16. M. Muro, and P. Jeffrey. A critical review of the theory and application of social learning in participatory natural resource management processes. Journal of Environmental Planning and Management 51, pp. 325-344. (2008)

17. McCarthy, D.P. Daniel, D.C. Debbe, S. Graham, Whitelaw, G. Zachariah, and J.S. Leonard Tsuji. "A Critical Systems Approach to Social Learning: Building Adaptive Capacity in Social, Ecological, Epistemological (SEE) Systems," Ecology and Society, 16(3), (2011)

18. M. Pelling, J. Sharpe, L. Pearson, T. Abeling, A.G. Swarling, J. Forrester, and H. Deeming. Social Learning and Resilience Building in the emBRACE
Framework. Brussel: emBRACE Deliverable 4.3, (2015)

19. R. Joiner. Mechanisms of cognitive change in peer interaction: a critical review. Critical Review \# 60. Milton Keynes: Centre for Information Technology in Education, Open University, (1989)

20. G. Elwyn, T. Greenhalgh, and F. Macfarlane, Groups: A Guide to Small Group Work in Healthcare Management, Education and Research. Abingdon, Oxon: Radcliffe Medical Press, (2001)

21. W.J. Clinton. Lessons Learned from Tsunami Recovery: Key Propositions for Building Back Better. New York: Office of the UN Secretary General's Special Envoy for Tsunami Recovery, (2006)

22. S. Khasalamwa, "Is build back better' a response to vulnerability? Analysis of the post-tsunami humanitarian interventions in Sri Lanka," Norwegian Journal of Geography, 63 (1), pp. 73 - 88, (2009)

23. G. Ardhana, G. 2005. Local Wisdom to Overcome Social Problems Towards Ajeg Bali. [Online]. Available:

http://www.balipost.co.id/balipostcetak/2005/11/12/o 2.htm. diakses 14 November 2007

24. M. Yamani. "Strategy of forest protection based on Eman community customary law in Bengkulu," Journal of Law, Vol. 18, No.2, pp 175-192, April. 2011.

25. D. Hidayati, Ed., Gender Based Disaster Management. Jakarta, Indonesia: PT Dian Rakyat. (2012)

26. Widayatun and D. Hidayati, the Role of Local Wisdom in the Javanese Survival Strategy in Facing the 2006 Bantul Earthquake. Yogyakarta, Indonesia: Gajah Mada University Press, (2012)

27. Badan Koordinasi Nasional Penanggulangan Bencana. Report on the development of earthquake management in Yogyakarta and Central Java. Jakarta, Indonesia: Bulletin Bakornas PB, (2006)

28. D. Hidayati, "Coping strategies during the emergency of disaster: lessons learned from Bantul community in dealing with earthquake," Vol 7, No.1, pp.83-102. (2012)

29. L. K. Katherina, F. Alihar, T. Soetopo, and L. Pradipta. "the capacity of community in Medan city in responding environmental changes and floods," Paper of the P2K Final Seminar, the Indonesian Institute of Sciences, Des, 2017.

30. Sajogyo and P.Sajogyo. The Role of Women in Families, Households and the Wider Community in the Rural Areas. Jakarta, Indonesia: CV Rajawali, (1983)

31. S.D. Brody. "Policy learning for flood mitigation: A longitudinal assessment of the community rating system in Florida," Risk Anal, 29, pp. 912-229, (2009)

32. E.A. Albright. "Policy Change and Learning in Response to Extreme Flood Events in Hungary: An Advocacy Coalition Approach," Policy Stud J, 39, pp. 485-511, (2011) 
33. J.P. Mulilis, T.S. Duval, R. Rogers. "The effect of a swarm of local tornados on tornado preparedness: a quasi-comparable cohort investigation," J. Appl. Soc.Psychol, 33 (8), pp. 1716-1725, (2003)

34. J.S. Becker, D.Paton, D.M. Johnson, K.R. Ronan, and J. McClure. ". The role of prior experience in informing and motivating earthquake preparedness," International Journal of Disaster Risk Reduction 22, pp. 179-193, (2017)

35. I.A.P. Putri, D. Hidayati. H. Yogaswara, and A.Y. Abdurrahim. "the capacity of community in responding environmental changes and disasters," Paper of the P2K Final Seminar, the Indonesian Institute of Sciences, Indonesia, Des, 2017.

36. S.R. Giyarsih and S.A. Dalimunthe. Surviving the Bantul Earthquake: Perspective from Livelihood Aspect. Yogyakarta, Indonesia: Gajah Mada University Press, (2012)

37. Bappenas, Main Book: Action Plan for Rehabilitation and Reconstruction in Post Earthquake Disaster Areas in the Province of Yogyakarta and the Province of Central Java. Jakarta: Government Report, (2006) 